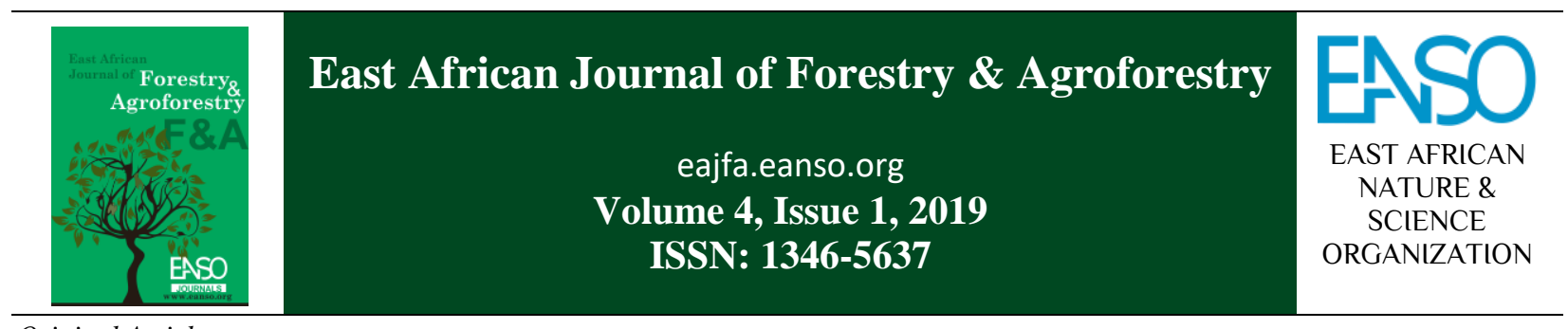

Original Article

\title{
CONSERVATION OF URBAN FOREST IN TANZANIA: COMMUNITY ATTITUDES TOWARDS NJIRO FOREST, ARUSHA
}

\author{
Goodluck Peter Massawe ${ }^{1}$; Wilfred Njama Marealle, $P h D^{2}$; \\ Stephen David Liseki, $P h D^{3}$ \& Giuseppe Camerini, $P h D^{4}$ \\ ${ }^{1}$ Tanzania Wildlife Research Institute, Arusha, Tanzania, goodluck.massawe@tawiri.or.tz. \\ ${ }^{2}$ Tanzania Wildlife Research Institute, Arusha, Tanzania, wilfred.marealle@tawiri.or.tz. \\ ${ }^{3}$ Tanzania Wildlife Research Institute, Arusha, Tanzania, steven.liseki@ tawiri.or.tz. \\ ${ }^{4}$ Istituto Scolastico Statale “Taramelli-Foscolo” Pavia- Italy, giuseppe_camerini@libero.it.
}

\section{Article history:}

Received: 16 Jul 2019

Accepted: 31 Jul 2019

Revised: 03 Aug 2019

Published: 26 Aug 2019

Keywords:

Njiro forest, Conservation,

Local community, Bees

\begin{abstract}
Understanding community attitudes towards urban forests is of great importance since these attitudes are inherently linked to the long-term sustainability of urban forests management and conservation. We analysed the attitudes of the local community towards the Njiro forest (Arusha, Tanzania) which is managed and used as an experimental beekeeping area by TAWIRI (Tanzania Wildlife Research Institute). Data collection was done between September-October 2018 involving a sample of 163 randomly selected respondents. A semi-structured questionnaire was used to collect the data. Quantitative data were analysed through Statistical Packages for Social Sciences (SPSS). Chi-square tests and contingency tables were used to determine whether there was a significant difference between the expected frequencies and the observed frequencies in one or more categories. Possible influences coming from sociological and demographic factors such as age, gender, education level, occupation were assessed. The majority of the respondents declared to gain ecological benefits from the forest. A significantly larger group of older respondents in comparison with the younger ones $(\mathrm{p}<0.05)$ declared to face problems coming from the forest (stray dogs, robbers, illegal waste disposal). Males showed to be more interested in practising beekeeping than females $(\mathrm{p}<0.05)$. Respondents with a primary education level were more prone to express agreement with the adopted management strategies in comparison with respondents with higher education $(\mathrm{p}<0.001)$. In conclusion, the great majority of respondents declared to support the conservation of Njiro forest, however, employed respondents and females were more positive regarding the hypothesis of abolishing the forest $(\mathrm{p}<0.05)$. In order to improve management strategies and support the long-term conservation of the forest, respondents recommended strengthening the protection of the forest by fencing it, providing environmental education to the surrounding community, reinforcing the cooperation with the local community and planting new trees to improve the health of the forest ecosystem.
\end{abstract}




\section{INTRODUCTION}

The world is increasingly becoming urban. Until the first half of the $19^{\text {th }}$ century, the majority of the human population lived in rural areas, but thereafter, new urbanization trends have changed the population distribution. According to the UN report, by 2030 the percentage of urban population will have risen to $60 \%$ (United Nations, 2018). Human populations are rapidly increasing especially in developing countries; by 2050 , more than half of the global population growth is expected to be recorded in Africa (United Nations, 2018).

Population growth and urbanization are a significant threat to wildlife (Cincotta et al., 2000). When new urban agglomerates or cultivations replace forests growing across tropical areas the impact is of particular concern since these areas often play the role of hotspots by hosting a very high degree of biodiversity (Allnutt et al. 2008; Gardner et al., 2009). Indeed, urbanization tends to modify the structure of the ecological niches and habitats of living organisms by both destroying the biodiversity and homogenizing the composition of the community itself (McKinney, 2006; 2008). Several critical factors linked to urbanization tend to work as limiting factors for wildlife. They are fragmentation and isolation of green areas surviving into cities, simplification of plant community structures, and colonization by exotic species, which tend to compete with indigenous ones, air and noise pollution, artificial night lighting, animals/vehicle collisions (Blair and Launer, 1997; Marzluff and Ewing, 2001; Picchi et al., 2013).

Increasing urbanization also poses critical pressure to urban forests by challenging their role as key providers of ecological services (Nowak and Crane, 2000). It is universally recognized that urban forests can mitigate air pollution, reduce temperature, provide carbon sequestration, draining of rainfall and work as recreational areas (Bolund and Hunhammar, 1999; Gill et al., 2007; Fuwape and Onyekwelu, 2011; Patarkalashvili, 2017). The management of biological resources needs careful consideration of the people's attitude towards their conservation and the urban forests are no exception (Kideghesho et al., 2007). Conservation efforts tend to fail when management strategies of a protected area do not appropriately take into account the opinions and aspirations of the surrounding human community (Odebiyi et al., 2015). Attitudes of people living around a protected area have therefore to be understood and incorporated in the management strategies

This paper reports the results of a survey on the attitudes and perception of the community towards Njiro forest management and conservation. Njiro forest (Arusha, Tanzania) is managed and used as an experimental beekeeping area by TAWIRI (Tanzania Wildlife Research Institute). The conservation of Njiro Forest, that serves as habitat and foraging area for both stinging and stingless bees, is of particular relevance in order to support their populations dynamics and conservation (Steffan-Dewenter et al., 2002; Carvell et al., 2006; Winfree et al., 2007; Wojcik et al., 2008; Hoehn et al., 2008). The study aimed at analysing local community support towards conservation of Njiro forest; perceptions of the local community towards the management and conservation of the forest; community understanding of beekeeping practices and the interest of the local community in being involved in beekeeping.

\section{MATERIALS AND METHODS}

\section{Study Area}

Tanzania is the largest country in Eastern Africa with an area of 937,062 sq. Km. It is located between latitudes $29^{\circ} 27^{\prime} \mathrm{S}$ and $40^{\circ} 20^{\prime} \mathrm{S}$ and had a population of 55.5 million inhabitants in 2016. Tanzania is one of the nine countries in the world that altogether will give a demographic contribution of more than half of the projected increase to the global population by 2050 (UN, 2019). Urban forests have survived as green patches in several cities, municipalities and other forms of townships in the country. The study area is included in the Arusha urban district, which includes the regional and economic capital itself (Arusha). The district is crossed by the Great Rift Valley north to south and elevations range from 900 to $1600 \mathrm{~m}$ above the sea level.

Arusha has a subtropical highland climate. Arusha City (341,136 inhabitants; $1263 \mathrm{~m}$ asl) is located in 
North-Eastern Tanzania. It is endowed with 12 urban forests, including Njiro Acacia Forest. This 25-hectare forest is part of Plot No 213 Block A, (Figure 1). The Forest is located $7 \mathrm{~km}$ South of Arusha City Centre. Njiro forest is a secondary forest dominated by a variety of Acacia species, such as Acacia seyal, A. polyacantha, A. nilotica and $A$. xanthophloea. It also includes other species, such as Vernonia exserstiflora, Rhus natalensis, Albizia harveyi, Grewia bicolor, Agave sisalana, Strychnos spinosa, Rauvolfia caffra and Albizia petersiana among others.

The forest area harbours a number of small mammals, more than 60 species of birds and a rich butterfly community (Mrisha, et. al. 2011). The forest is surrounded by TAWIRI (Tanzania
Wildlife Research Institute) offices and several other urban settlements. The forest is well patrolled by qualified security guards and demarcated by signboards that restrict trespassing. It is surrounded by people of different cultural identities, both residents and non-residents, living around the forest.

Njiro forest is used for field practical studies by local college and university students, as well as for beekeeping production and research purposes. The forest hosts 14 experimental apiaries inhabited by honeybees belonging to Apis mellifera scutellata. In this forest, several stingless bee species have also been recorded. They belong to the following genera: Melipona, Meliponula, Trigona, and Dactylurina (TAWIRI, unpublished data).

Figure 1: Location of Njiro Forest Found in Arusha Region
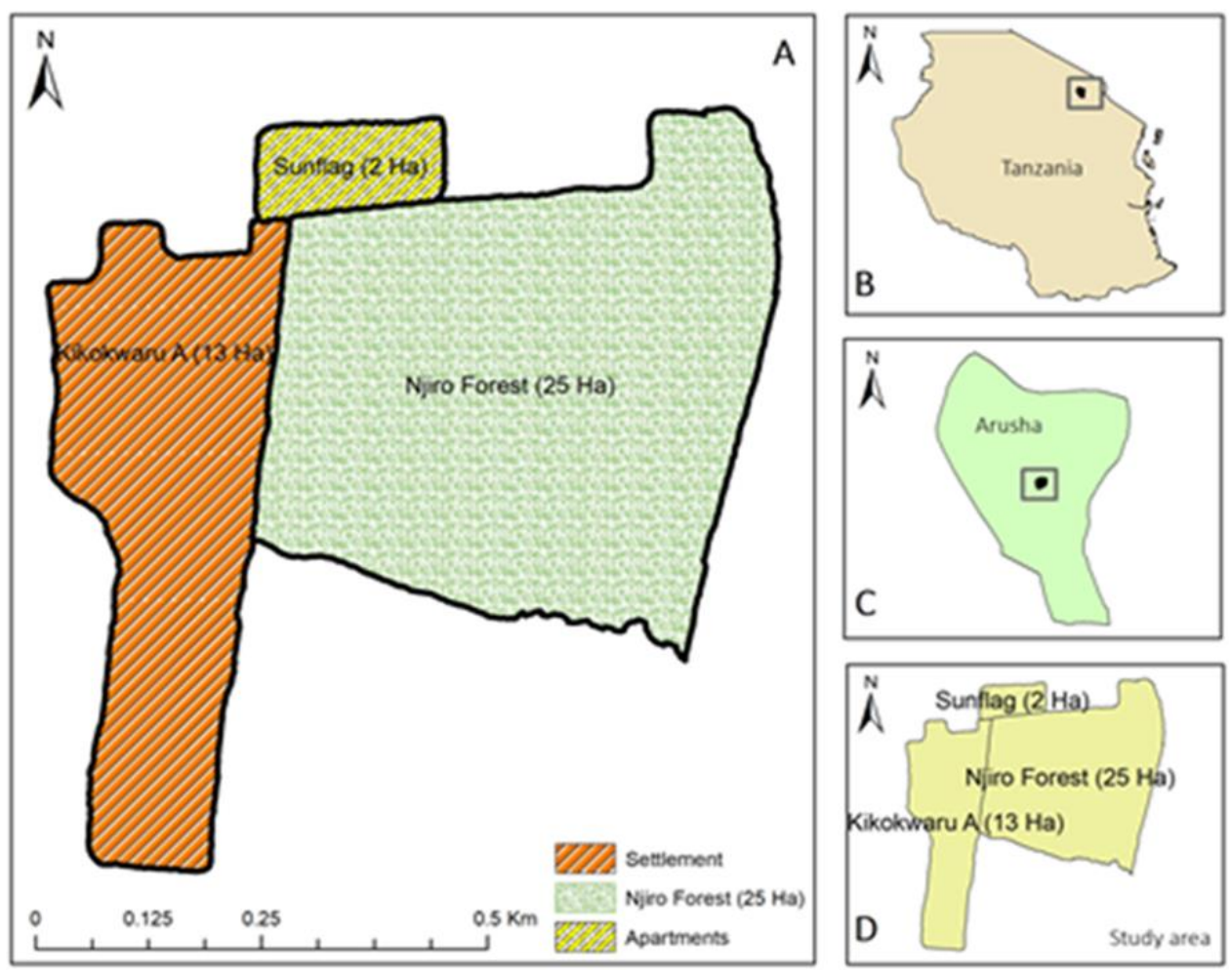
Figure 2: The overlay of Njiro urban forest and its surrounding community

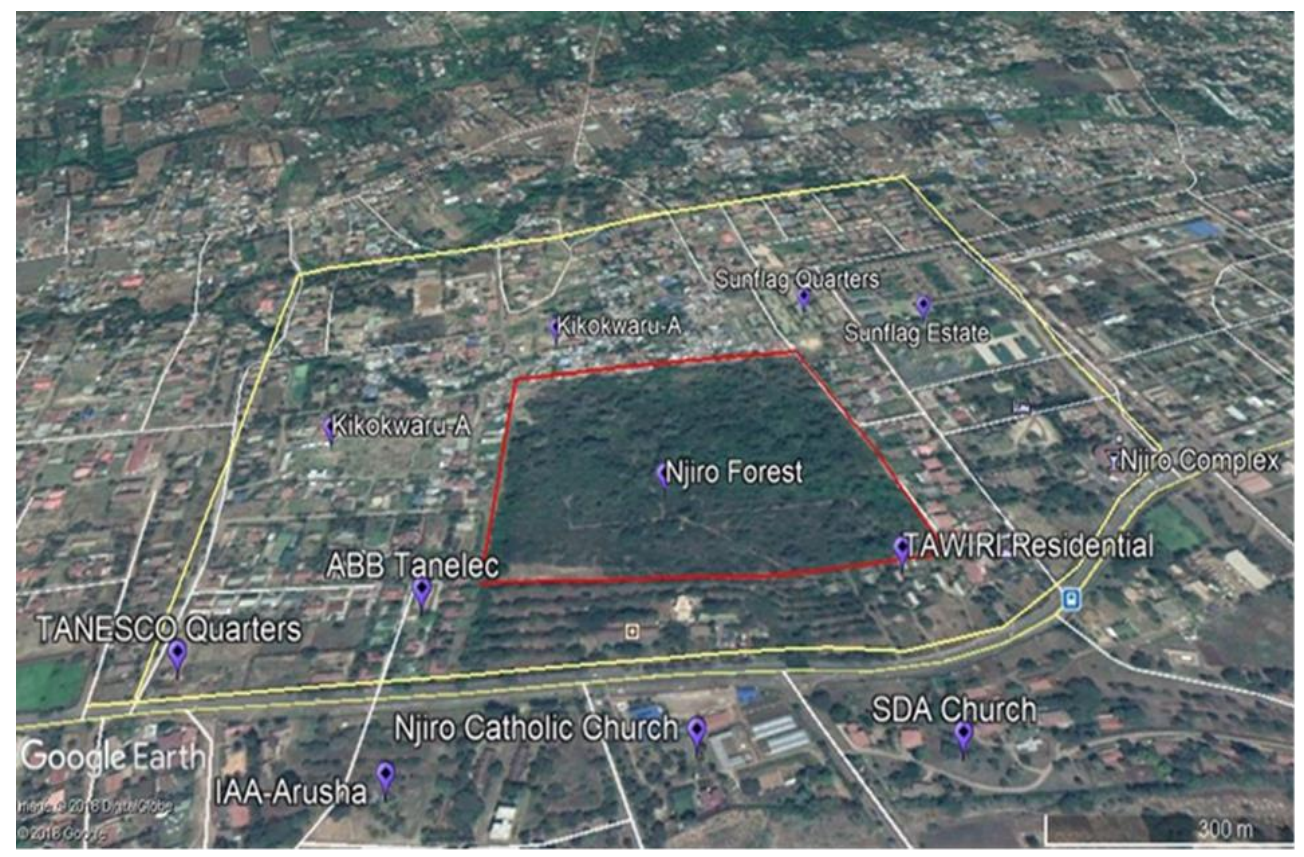

Source: The Image was extracted from Google Earth Software in September 2018

\section{Data Collection}

Questionnaire survey technique was employed for data collection. A sample of members of the community living in the areas around the forest was surveyed by means of a questionnaire between September-October 2018. The areas surrounding the forest are namely Kikokwaru-A, Sunflag quarters, and Sunflag-building- estate. The respondents were selected randomly from these areas. The sample size was determined by Cochran's formula (Cochran, 1963 as quoted in Israel 1992). The equation is given as:

$$
n_{0}=\frac{Z^{2} p q}{e^{2}}
$$

where $n$ is the sample size, $Z$ is the abscissa of the normal curve ( $\mathrm{Z}$ score), $p$ is the degree of variability in the population, $q$ is 1-p and $e$ is the desired level of precision (sampling error). Household heads (main targets) were interviewed face-to-face. In their absence, any member of the household over 18 years old was interviewed.

\section{Data Preparation and Analysis}

The questionnaire survey involved 163 respondents. Their attitudes were analysed by means of 12 statements, using a 3-point scale: disagreement, agreement and undecided position. Chi-square test was used to assess whether the difference between the expected frequencies and the observed ones was significant. In case of multiple categorical variables, expected and observed frequencies were compared by means of a contingency table, to test the possible influence on respondent's opinion of the following factors: Gender (male/female); Age ( $<40$ years old- / >40 old); Level of education (Primary School/Secondary School and University) and Working condition (employed/unemployed).

\section{RESULTS AND DISCUSSION}

\section{Demographic and Socio-Economic Conditions}

The age of respondents ranged from 20 to 79 . The majority of respondents $(68.7 \%)$ were household's heads. The number of males (table 1) was not significantly different from the number of females 
( $>$ >0.05). Sex distribution within the sample is of great importance, because some attitudes are sexdependent, especially in African countries (Lazaro et al., 2013). For example, males have easier access to information and usually have a prominent role in the households' decision-making process. In addition, males are highly involved in forest-related activities (i.e. beekeeping) when compared to females (Steriani and Soustas, 2005; Lazaro et al., 2013). On the other hand, males are usually less sensitive and less concerned with environmental protection, compared to females (Zelezny et al., 2000; Chun et al., 2012).

With regard to education (table 1), a minority part of the sample (39.3\%) had an education level higher than primary school. In addition, the survey revealed a significant rate of unemployment $(65.6 \%)$. Self-employed (22.9\%) depended on business as a major source of income. The main sources of income of respondents can significantly affect the attitudes of stakeholders towards environmental resources conservation. Ntongani et al. (2010) for example, found that the expansion of land for agricultural activities had been threatening the conservation of Selous-Niasa Miombo woodland ecosystem in Nachingwea, Tanzania. Given the importance of business as an incomegenerating activity in the study area, future pressure on land for new settlements and the establishment of business centres could be expected.
Table 1: Demographic Characteristic

\begin{tabular}{ll}
\hline Characteristics of respondents & $\%$ \\
\hline Age & \\
$<40$ & 61.3 \\
$\geq 40$ & 38.7 \\
\hline Gender & \\
$\quad$ Males & 54.6 \\
$\quad$ Females & 45.4 \\
\hline Education level & \\
$\quad$ Primary & 60.7 \\
$\quad$ Secondary/University & 39.3 \\
\hline Occupation & \\
$\quad$ Unemployed & 62.6 \\
$\quad$ Employed & 23.9 \\
$\quad$ Self-employed & 13.5 \\
\hline
\end{tabular}

\section{Benefits and problems deriving from Njiro Forest}

Almost all the respondents $(97.5 \%)$ declared to be aware of the existence of Njiro forest. Most of the respondents $(69.3 \%)$ declared to gain benefits from the forest: ecological services, honey, timber, medicines (see Figure 3). These findings are similar to the ones observed by Hassan (2015) who observed that the majority of the local community in Dar es Salaam (Tanzania) thinks that conservation of open spaces is costing, but also beneficent. Several researchers all over the World recognized the ecological benefits of green spaces, demonstrating that urban forests and parks work as a beneficial space for physical and psychological wellbeing (Hartig et al., 2014; van den Berg et al., 2018; Wheeler et al., 2018).

Figure 3: Benefits from Njiro forest

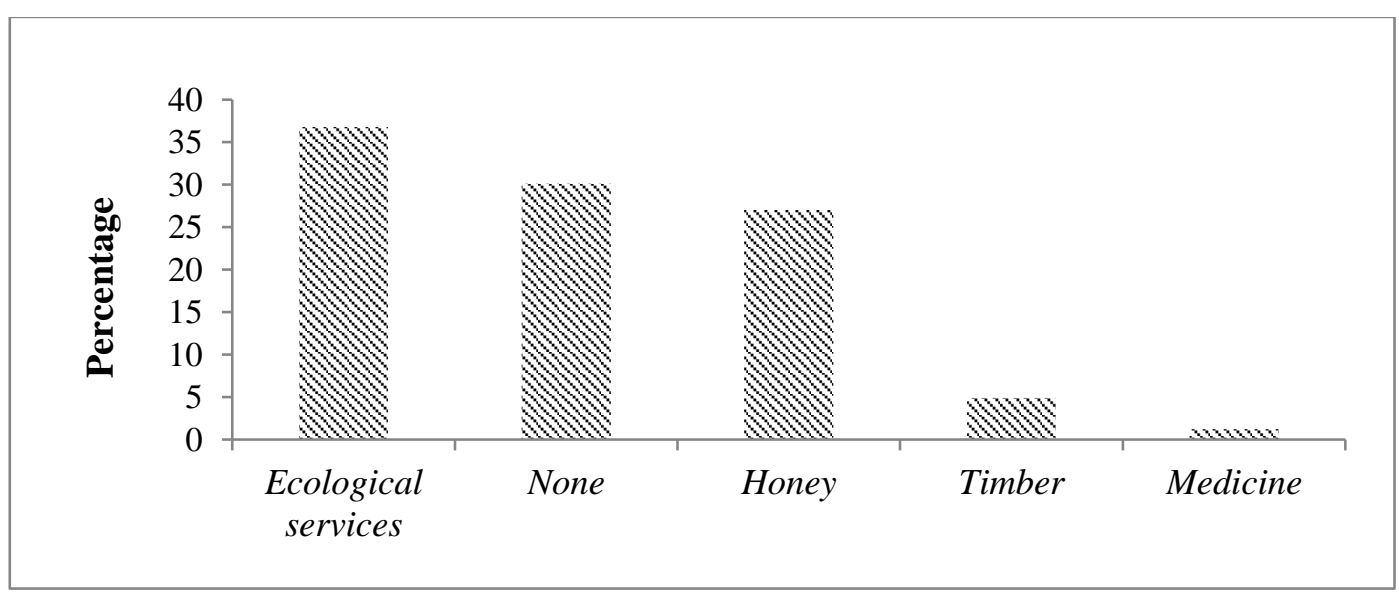


Problems coming from the forest were reported by (57.7\%) of respondents (Figure 4). Danger arising from stray dogs or robbers and the use of the forest as a waste disposal area are the main perceived threats (Figure 4). Respondents claimed that robbers have sometimes used the forest as a refuge to hide from security bodies and laws. As the forest lacks fencing, robbers can easily access to the wood.

\section{Figure 4: Problems deriving from Njiro forest}

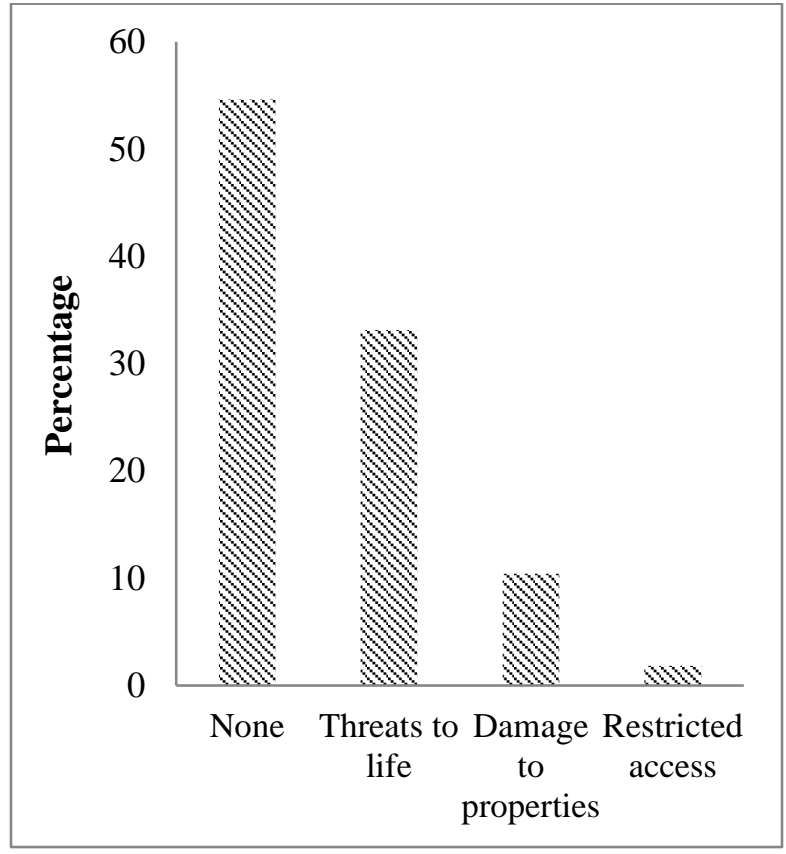

Populations of dogs freely roaming in public places can facilitate zoonotic disease transmission, such as rabies (Guilloux et al. 2018); for this reason, stray dogs can impact public health in urban areas (Guilloux et al. 2018). In addition, they can affect wildlife as predators when they forage along urban forest edges (Galetti and Sazima, 2006; Marks and Duncan, 2009).

The members of the local community living in the area surrounding Njiro Forest are the main cause of illegal waste disposal into the forest. Despite the agency responsible for the collection of solid waste usually sets specific days for cleaning the edges of the wood, but that intervention is not enough to solve the problem . Related studies on problems associated with urban forests conducted by Mariana et al (2014) demonstrated that also urban forests in Brazil are used for illegal dumping of waste.

\section{Living Conditions of Respondents Regarding the existence of Njiro forest}

A highly significant number of respondents (89.6\%) declared to be happy to live near Njiro forest, but this opinion is not supported by economic advantages coming from the forest conservation. Indeed, a substantial number of respondents $(47.8 \%)$ declared that the forest existence did not improve their life conditions (Table 2) and did not bring development to the area around it (50.9\%). On the other hand, respondents mainly expressed the opinion (68.1\%) that forest conservation did not worsen the life condition of the people living around it (Table 2). Employed people were more negative $(66.1 \%)$ than unemployed ones $(48.2 \%)$ about the fact that the forest did not improve their living conditions $(\mathrm{p}<0.05)$. It can be reasonably hypothesized that green areas included in urban settlements are perceived as a factor limiting the economic development by people involved in the business.

Table 2: Contribution of Njiro Forest on the Living Conditions of Respondents

\begin{tabular}{ll}
\hline $\begin{array}{l}\text { Njiro forest brought } \\
\text { development to the area }\end{array}$ & $\%$ \\
\hline Yes & 30.1 \\
No & 50.9 \\
Don't know & 19 \\
\hline Njiro forest improved living & $\%$ \\
conditions & \\
Yes & 38.7 \\
No & 47.8 \\
Don't know & 13.5 \\
\hline Njiro forest worsened living & \\
conditions & \\
Yes & 19.6 \\
No & 68.1 \\
Don't know & 12.3 \\
\hline
\end{tabular}

\section{Knowledge about Bees and Bee Products}

Perception of benefits coming from natural beekeeping has a positive outcome for urban forest conservation, as demonstrated by Chanthayod et al (2017) as a result of a research carried out in North Lao. A few respondents (8.6\%) declared not to know bees while $(32.5 \%)$ (Table 3) have no 
knowledge of beekeeping practices in Njiro forest (Table 3). The younger generation is less aware of beekeeping (61\%) compared to the older one $(77.8 \% ; \mathrm{p}<0.05)$. The reason of such a difference could be that a large group of young people around the study area are University students; since those students are not native of the area, they have poor knowledge of the area where they live in.

The majority of respondents (63.2\%) would like to practice beekeeping, given the chance to do it. The percentage of males who wish to keep bees (71.9\%) is significantly higher than the one of females $(52.7 \% ; \mathrm{p}<0.05)$. Such a discrepancy has probably to be related to the almost exclusive role of men as beekeepers in African Countries (Ogaba, 2001). Nonetheless, beekeeping should not be considered solely a male activity; there is a need for promoting beekeeping as an income-generating activity also for women. Beekeeping practice should be viewed as a potential driver to empower women to take part in environmental projects (Iddi, 2002).

Table 3: Knowledge about Beekeeping

\begin{tabular}{ll}
\hline & $\%$ \\
\hline Do you know bees? & \\
Yes & 91.4 \\
No & 8.6 \\
\hline Do you have knowledge of \\
beekeeping? \\
Yes & 67.5 \\
No & 32.5 \\
\hline Do you wish to practice \\
beekeeping? \\
Yes & \\
No & 63.2 \\
\hline
\end{tabular}

The majority of respondents recognized honey as the main benefit coming from bees (Figure 5). Stingless bees are even more associated by respondents to the production of honey having healing properties. Probably this knowledge has been passed down to them by their ancestors. A similar result was achieved by Reyes-González et al. (2014) who studied the knowledge and use of stingless bees in Mexico. Surprisingly, very few respondents are aware of the important role of bees as pollinators (Figure 5).
Figure 5: Benefits from stinging and stingless bees

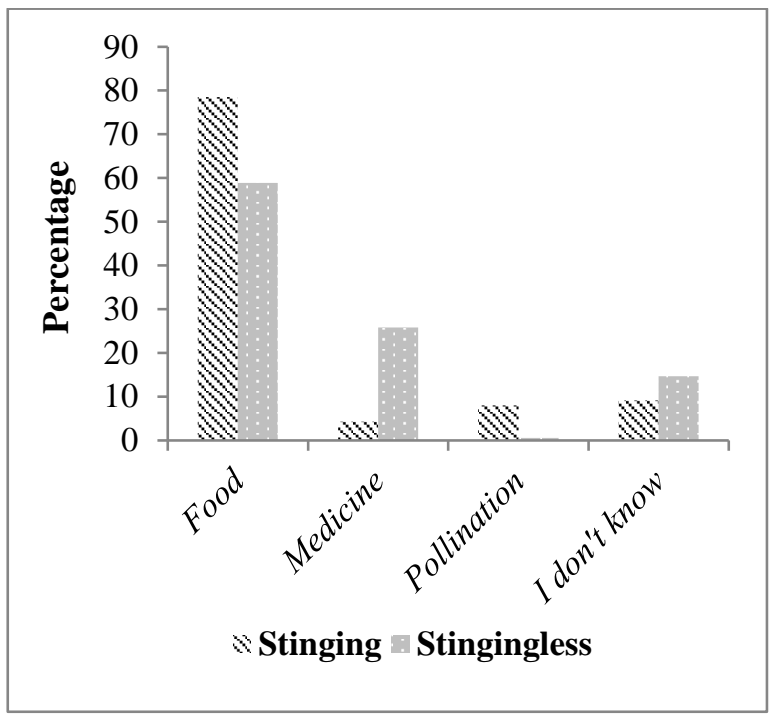

\section{Opinion on Forest Conservation Strategies}

The majority of respondents $(53.5 \%)$ agreed with management strategies and believed that the forest was well protected and managed (Figure 6). The trend of people who agree with management strategies was supported mainly by respondents having a primary level education (63.1\%) compared to respondents having a higher education level $(27.5 \%$ - $\mathrm{p}<0.001)$. This is further evidence that the level of education is a determinant driver for assessing the local community's attitudes on conservation (Steriani and Soutsas, 2005; Thiruchelvam and Kirupakaran, 2010; Mpokigwa et al., 2011; Chun et al., 2012).

Figure 6: Is the Njiro forest management effective?

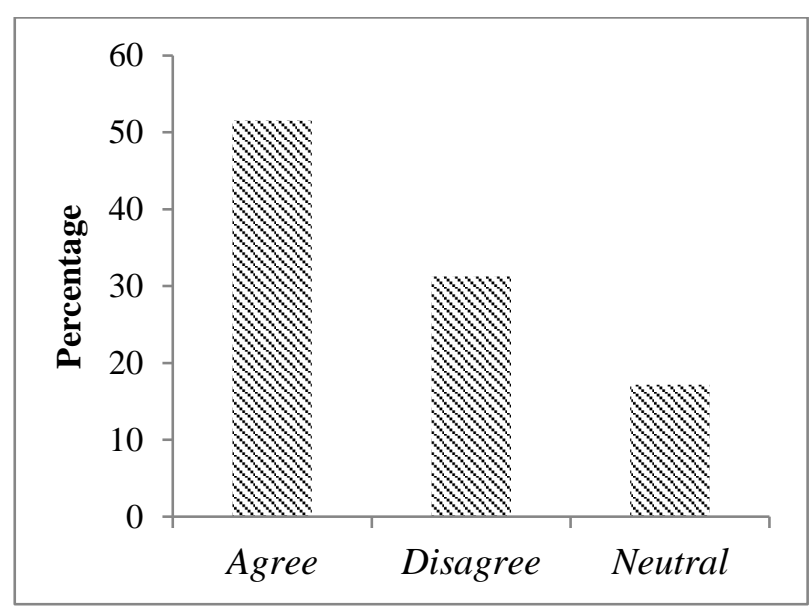


The opinion that Njiro forest is necessary for the protection of the remaining natural resources in the urban setting is largely rooted in the sample of respondents (Figure 7) as well as the idea that people should not be allowed to utilize the resource of the forest $(92.6 \%)$.

Figure 7: Njiro forest is necessary for the protection of remaining natural resources

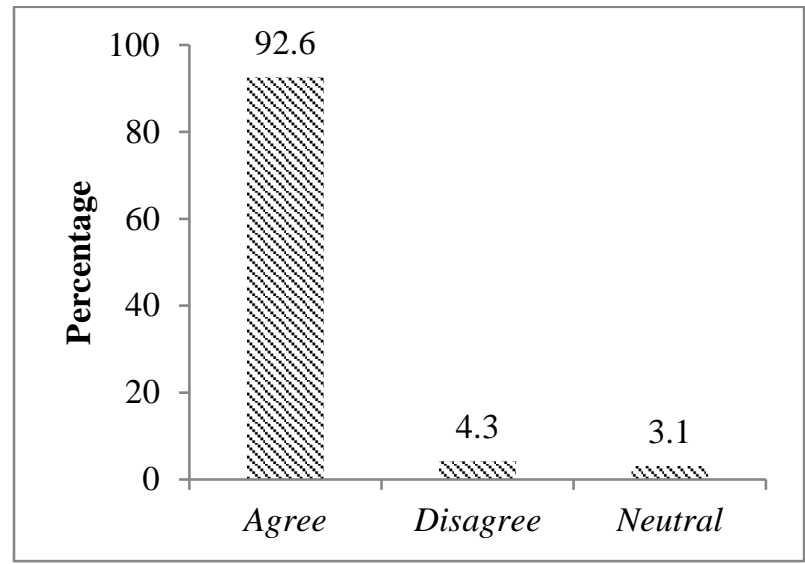

A critical point associated with the forest management is the perception of a poor involvement of the local community in decisions (Figure 8). The majority of the respondents indicated that is neither involved in decision making $(74.2 \%)$ nor encouraged to participate in conservation programs $(71.2 \%)$.

Figure 8: Involvement of the local community in decisions on management

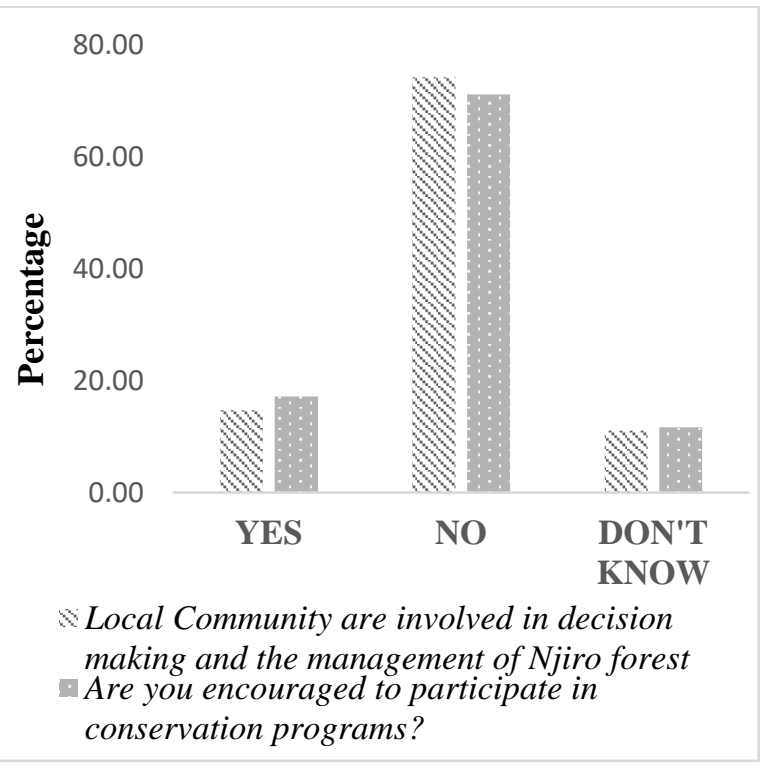

A large majority of respondents $(85.3 \%)$ disagree with the idea of abolishing the forest as they receive ecological benefits from the forest (Table 4). Females (20.3\%) and employed people (21.7\%) are more supportive of the idea of abolishing Njiro forest and replace it with urban settings compared respectively to males (9\%) and unemployed people $(9.8 \% ; \mathrm{p}<0.05)$. The main reason why a substantial part of women does not agree with the conservation of the forest is probably the perception of the forest as a source of danger. This negative attitude expressed by females is in contrast with the trend showing a general positive attitude of women to biodiversity conservation (Czech et al., 2001; Uliczka et al., 2004; Agarwal, 2009). The same negative attitude expressed by numerous employed respondents, as previously discussed, could be related to the idea that the forest existence is not useful to promote local economic activities.

Table 4: Njiro forest management and existence

$\%$

Is the management of Njiro forest effective?

Agree

51.5

Disagree

Don't know

Should be Njiro forest abolished?

Yes

No

Which type of Institution is responsible for Njiro Forest management?
Government
Partnership
Local Community
Don't know

\section{Institution responsible for $\mathrm{Njiro}$ forest management and support to conservation}

The majority of respondents $(68.7 \%)$ want the government to be directly responsible for the forest management, but some of the respondents $(23.9 \%)$ would like management based on partnership with the local community (Figure 9). Amoah and Wiafe (2012) reported similar opinions expressed by the local community living next to Kakum National Park in Ghana. Collaborative management should 
be given the necessary consideration, bearing in mind the fact that most protected area managers are well equipped to carry out their mandates effectively when they are supported by of the local community (Allendorf et al., 2006).

Figure 9: Who should be responsible for forest management?

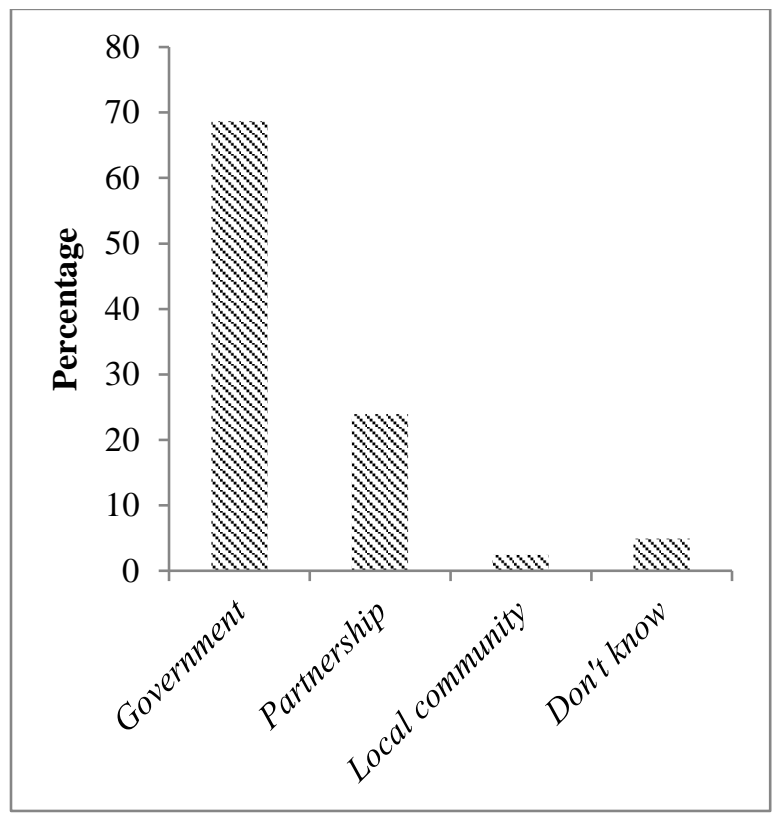

Respondents were also asked to suggest which type of direct benefit would fully support the management and conservation of the forest (Figure 10). Being employed in the staff of management is the most frequent aspiration desire (53.4\%).

Figure 10: What will make you fully support conservation programs?

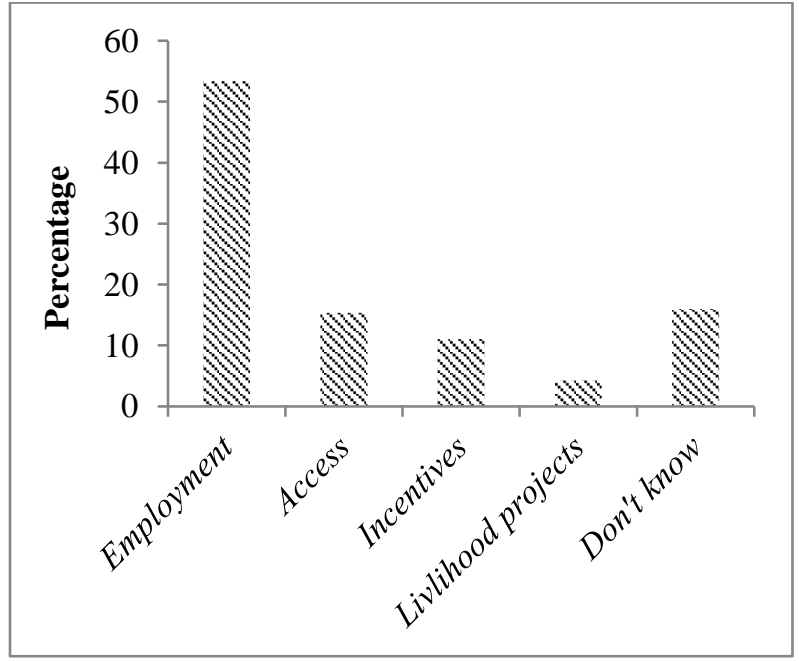

\section{Opinions on the Improvement of Njiro Forest}

A number of recommendations from the local community were suggested for further improvement of Njiro forest conservation.

Table 5: Opinions on possible actions supporting Njiro forest conservation

\begin{tabular}{ll}
\hline Opinion & $\%$ \\
\hline Protection /Fencing & 33.1 \\
Environmental education & 18.4 \\
Community involvement & 8.6 \\
Keep the area clean & 8.6 \\
Planting trees & 8.0 \\
Business area & 5.5 \\
Forest as an area of attraction & 4.3 \\
Don't know & 13.5 \\
\hline
\end{tabular}

1. Fencing/protection: When the forest is located in a highly urbanized area, a fence is an effective tool for limiting illegal human encroachment and deter from illegal waste disposal.

2. Education on beekeeping and conservation training: education on the importance of forest conservation and promotion of beekeeping as a local activity capable of generating income is suggested by respondents in order to reinforce the involvement of people in active forest management.

3. Cooperation: The management of Njiro forest should be based on good relationships with the local community and its involvement in conservation activities, which can positively affect the local community attitude towards the protected area.

4. Replant new trees. The local community thinks that the environmental quality of the forest can be improved. This opinion can support also the suitability of the forest as foraging habitat for bees. There is a need to plant tree species to attract bees, since over $75 \%$ of the forest is dominated by invasive vegetation, including many species that are not palatable/attractive to bees. A renewal of wood composition can enrich the carrying capacity of the area in terms of bee foraging. 
Law enforcement: It is important to have enforceable bylaws, which is the best tool to achieve effective conservation of the forest.

\section{CONCLUSION}

The local community is or are aware of the legislation governing the conservation of Njiro forest in Arusha. The majority of respondents disagreed with the hypothesis that Njiro forest should be abolished. The majority of the local community also agrees with the management pattern that up to now has been adopted, supporting the conservation of the forest as an ecological service provider, a biodiversity reservoir and an important area for beekeeping and research. The public acceptance of Njiro forest protection was positive, but the local community suggests some actions to be planned by the management: fencing the forest, involving the community in decisions on forest management, providing environmental education to the local community. More specifically, it is urged to promote the involvement of the local community in management decisionmaking; otherwise, future support to forest conservation could seriously decline. In addition, it is fundamental to conduct further research to monitor both the changes in the attitudes of the local community in response to the implementation of actions suggested by the community and extending more research projects on other urban forests located in Tanzania.

\section{ACKNOWLEDGEMENT}

We render our thanks to Tanzania Wildlife Research Institute for providing us with a research permit. We also acknowledge the support of data collection from Fredrick N. Mbamange and Sylivester P. Benard who volunteered at TAWIRI (September-October 2018); We also thank all the respondents who provided us with information and Monica Masanta for final text revision.

\section{REFERENCES}

Agarwal, B. (2009). Gender and forest conservation: The impact of women's participation in community forest governance. Ecological Economics, 68(11), 2785-2799.
Allendorf, T.D., Swe, K.K., Oo, T., Htut, Y., Aung, M., Aung, M. (2006). Community attitudes toward three protected areas in Upper Myanmar (Burma). Environmental Conservation, 244-352.

Allnutt, T. F., Ferrier, S., Manion, G., Powell, G. V., Ricketts, T. H., Fisher, B. L., and Lees, D.C. (2008). A method for quantifying biodiversity loss and its application to a 50-year record of deforestation across Madagascar. Conservation Letters, 1(4), 173-181.

Amoah, M. and Wiafe, E.D. (2012). Livelihoods of fringe communities and the impacts on the management of conservation area: the case of Kakum National Park in Ghana. International Forestry Review, 132-144.

Blair, R.B. and Launer, A.E. (1997). Butterfly diversity and human land use: Species assemblages along an urban gradient. Biological Conservation, 80, 113-125.

Bolund, P. and Hunhammar, S. (1999). Ecosystem services in urban areas. Ecological Economics, 29(2), 293-301.

Carvell, C., Roy, D. B., Smart, S. M., Pywell, R. F., Preston, C. D. and Goulson, D. (2006). Declines in forage availability for bumblebees at a national scale. Biological Conservation, 132 4:481-489.

Chanthayod, S., Zhang, W. and Chen, J. (2017). People's perceptions of the benefits of natural beekeeping and its positive outcomes for forest conservation: a case study in Northern Lao PDR. Tropical Conservation Science, 10, 1940082917697260.

Cincotta, R. P., Wisnewski, J. and Engelman, R. (2000). Human population in the biodiversity hotspots. Nature, 404 (6781), 990.

Czech, B., Devers, P. K. and Krausman, P. R. (2001). The relationship of gender to species conservation attitudes. Wildlife Society Bulletin, 187-194.

Chun, M. H., Suleiman, W. N. A. and Samah, M. A. A. (2012). A case study on public participation for conservation of a tropical urban river. Political Journal of Environment Studies 21(4), 821 - 829 . 
East African Journal of Forestry and Agroforestry, 4(1), 2019

Fuwape, J. A. and Onyekwelu, J. C. (2011). Urban forest development in West Africa: benefits and challenges. Journal of Biodiversity and Ecological Sciences (JBES) 1 (1), 77 - 94.

Galetti, M. and Sazima, I. (2006). Impact of feral dogs in an urban Atlantic forest fragment in southeastern Brazil. Natureza e Conservação, 4(1), 146-151.

Gardner, T. A., Barlow, J., Chazdon, R., Ewers, R. M., Harvey, C. A., Peres, C. A., and Sodhi, N. S. (2009). Prospects for tropical forest biodiversity in a human-modified world. Ecology Letters, 12(6), 561-582.

Gill, S. E., Handley, J. F., Ennos, A.R. and Pauleit, S. (2007). Adapting cities for climate change: The role of the green infrastructure. Built Environment, 33(1), 115-133. https://doi.org/10.2148/benv.33.1.115

Guilloux A.G.A., Panachão L.I., Alves A.J.S., Cassenote A.J.F. and Dias R.A. (2018). Stray dogs in urban fragments: the relation between population's perception of their presence and socio-demographic factors.Pesquisa Veterinária Brasileira, 38(1), 89-93.

Hartig, T., Mitchell, R., de Vries, S. and Frumkin, H. (2014). Nature and Health. Annual Review of Public Health, 35(1), 207-228. https://doi.org/10.1146/annurev-publhealth032013-182443.

Hassan, A. (2015). Assessment of community's participation in conservation of open spaces in Dar es Salaam city, Tanzania (Doctoral dissertation, Sokoine University of Agriculture).

Hoehn, P., Tscharntke, T., Tylianakis, J. M. and Steffan-Dewenter, I. (2008). Functional group diversity of bee pollinators increases crop yield. Proceedings of the Royal SocietyB., 275(1648), 2283-2291.

Iddi S. (2002). Community participation in forest management in the United Republic of Tanzania. In: Proceedings of the Second International Workshop on Participatory Forestry in Africa: 59-67.
Kideghesho, J. R., Roskaft, E. and Kaltenborn, B. P. (2007). Factors influencing conservation attitudes of local people in western Serengeti, Tanzania, 2230.

Lazaro, M., Shemdoe, R. S. and Emma, L. (2013). Community Perceptions and Willingness to Accept and Execute REDD+ Initiative: The Case of Pugu and Kazimzumbwi Forest. CrossCultural Communication, 9(3), 48-54.

Marks, B. K. and Duncan, R. S. (2009). Use of forest edges by free-ranging cats and dogs in an urban forest fragment. Southeastern Naturalist, 8(3), 427-437.

Marzluff, J. M. and Ewing K. (2001). Restoration of Fragmented Landscapes for the Conservation of Birds: A General Framework and Specific Recommendations for Urbanizing Landscapes. Restoration Ecology, 9, 280-292.

McKinney, M. L. (2006). Urbanization as a major cause of biotic homogenization. Biological Conservation, 127, 247-260.

McKinney, M. L. (2008). Effects of urbanization on species richness: A review of plants and animals. Urban Ecosystems, 11, 161-176.

Mpokigwa, M. K., Sangeda, A. Z. and Iddi, S. (2011). Toward communication, education and awareness rising for participatory Forest management: A case study of Mufindi District, Tanzania. International Journal of Social Forestry 4(1), $17-31$.

Mrisha, C. K., Mwita, M., Marealle, W. N. and Kija, H. (2011). Updates of birds species diversity of Njiro forest and the surrounding area. Paper presented at the Eighth TAWIRI Scientific conference, Corridor Springs, Arusha, Tanzania.

Ntongani, W. A., Munishi, P. K. T. and Mbilinyi, B. P. (2010). Land-use changes and conservation threats in the eastern Selous-Niassa wildlife corridor, Nachingwea, Tanzania. African Journal of Ecology, 48(4), 880 - 887.

Nowak, D. J. and Crane, D. E. (2000). The Urban Forest Effects UFORE Model: quantifying urban forest structure and functions. In: Hansen, Mark; Burk, Tom, eds. Integrated tools for natural 
East African Journal of Forestry and Agroforestry, 4(1), 2019

resources inventories in the 21 st century. Gen. Tech. Rep.

Ogaba, M. R. (2001). Gender issues in beekeeping: the Uganda case. Proceedings of the 37th International Apicultural Congress, Durban, South Africa: APIMONDIA

Odebiyi, B. R., Ayeni, S. M., Umunna, M. O. and Johnson, J. J. (2015). Communities attitudes towards conservation in Gashakagumti National Park Nigeria. Journal of Research in Forestry, Wildlife and Environment, 7(2), 67-80.

Patarkalashvili, T. K. (2017). Annals of Agrarian Science Urban forests and green spaces of Tbilisi and ecological problems of the city. Annals of Agrarian Sciences, 15(2), 187-191. https://doi.org/10.1016/j.aasci.2017.03.003

Picchi, M. S., Avolio, L., Azzani, L., Brombin, O. and Camerini, G. (2013). Fireflies and land use in an urban landscape: the case of Luciola italica L. (Coleoptera: Lampyridae) in the city of Turin. Journal of insect conservation, 17(4), 797-805.

Reyes-González, A., Camou-Guerrero, A., ReyesSalas, O., Argueta, A. and Casas, A. (2014). Diversity, local knowledge and use of stingless bees (Apidae: Meliponini) in the municipality of Nocupétaro, Michoacan, Mexico. Journal of Ethnobiology and Ethnomedicine, 2014, 10:47 Page 2 of 12

http://www.ethnobiomed.com/content/10/1/47.

Steffan-Dewenter, I., Munzenberg, U., Burger, C., Thies, C. and Tscharntke, T. (2002). Scaledependent effects of landscape structure on three pollinator guilds. Ecology,83, 1421-143.

Steriani, M. K. and Soutsas, K. P. (2005). Recreation Demand Model Construction Through the Use of Regression Analysis with Optimal Scaling. Mediterranean Journal of Economics, Agriculture and Environment, 4(4), $25-30$.

Thiruchelvam, S. and Kirupakaran, S. (2010). Coastal community' attitudes towards conservation of freshwater Turtle in Ampara District. Tropical Agricultural Research 21(4): $427-434$.
Uliczka, H., Angelstam, P., Jansson, G. and Bro, A. (2004). Non-industrial private forest owners' knowledge of and attitudes towards nature conservation. Scandinavian Journal of Forest Research, 19(3), 274-288.

United Nations. (2018). The World's Cities in 2018- Data Booklet. Retrieved on 09 April 2019from

https://www.un.org/en/development/desa/popula tion/publications/index.asp.

United Nations. (2019). World Population Prospects 2019. Highlights. 46 pp.

Van den Berg, M., van Poppel, M., van Kamp, I., Andrusaityte, S., Balseviciene, B., Cirach, M. and Maas, J. (2016). Visiting green space is associated with mental health and vitality: A cross-sectional study in four European cities. Health \& Place, 38, 8-15.

Winfree, R., Griswold, T. and Kremen, C. (2007). Effect of human disturbance on bee communities in a forested ecosystem. Conservation Biology!: The Journal of the Society for Conservation Biology, 21(1), 213-23.

Wheeler, B. W., Lovell, R., Higgins, S. L., White, M. P., Alcock, I., Osborne, N. J. and Depledge, M. H. (2015). Beyond greenspace: an ecological study of population general health and indicators of natural environment type and quality. International Journal of Health Geographics, 14(1), 17. https://doi.org/10.1186/s12942-0150009-5

Wojcik, V. A., Frankie, G. W., Thorp, R. W. and Hernandez, J. L. (2008). Seasonality in Bees and Their Floral Resource Plants at a Constructed Urban Bee Habitat in Berkeley, California. Journal of the Kansas Entomological Society, 81(1),15-28.

Zelezny, L. C., Chua, P. and Aldrich, C. (2000). Elaborating on gender differences in environmentalism. Journal of Social Issues, 56(3), $443-457$. 